\title{
THE ELECTABILITY OF ISLAMIC EDUCATIONAL INSTITUTIONS
}

\section{Bahar Agus Setiawan}

Universitas Muhammadiyah Jember

Jl. Karimata No. 49 Jember, Jawa Timur, Indonesia, 68121

Email: baharsetiawan@unmuhjember.ac.id

\section{Hairul Huda}

Universitas Muhammadiyah Jember

Jl. Karimata No. 49 Jember, Jawa Timur, Indonesia, 68121

Email: hairulhuda@unmuhjember.ac.id

\section{Sofyan Rofi}

Universitas Muhammadiyah Jember

Jl. Karimata No. 49 Jember, Jawa Timur, Indonesia, 68121

Email: sofyan.rofi@unmuhjember.ac.id.

Received: 11, 2019. Accepted: 06, 2020. Published: 06, 2020

\begin{abstract}
Islamic schools have participated in Indonesian educational market and they have shown significant developments both in their achievement and their images. Their competitiveness is reflected in the level of their electability which can be investigated from the survey. This study was aimed at investigating the principal component that influenced the electability of Islamic schools with the formulation of any variable problems that contributed significantly to the electability of Islamic schools. This research applied Principal Component Analysis (PCA) with a questionnaire instrument using nine variables with 72 measuring statements. There were 204 respondents took a part from MTsN (Madrasah Tsanawijyah Negeri/State Islamic Junior High School) 5 Jember and SMPIT (Sekolah Menengah Pertama Islam Terpadu/Integrated Islamic Junior High School) Al-Ghazali Jember. The results of this study showed the principal component in each Islamic school amounted to one with an eigen value of 6.3081 and 6.1140 . Based on the result of this study, some variables contributed significantly to the school electability and this was done by continuing the analysis until the proportion value was greater than 80 percent. The variables of principal, teachers and learning atmosphere influenced school electability at MTs Negeri 5 Jember and variables of school principals, teachers and infrastructure influenced significantly school electability at SMPIT Al-Ghazali.
\end{abstract}

Keywords: Competitiveness, Islamic Education Institution, Principal Component, Customer Satisfaction

\begin{abstract}
ABSTRAK
Sekolah-sekolah Islam telah berpartisipasi dalam pasar pendidikan Indonesia dan mereka telah menunjukkan perkembangan yang signifikan baik dalam prestasi dan citra mereka. Daya saing mereka tercermin dalam tingkat keterpiliban mereka yang dapat diselidiki dari survei. Penelitian ini bertujuan untuk menyelidiki komponen utama yang mempengarubi elektabilitas sekolah-sekolah Islam dengan rumusan masalah variabel yang berkontribusi signifikan terhadap elektabilitas sekolah-sekolah Islam. Penelitian ini menggunakan Principal Component Analysis (PCA) dengan instrumen kuesioner menggunakan sembilan variabel dengan 72 pernyataan pengukuran. Ada 204 responden mengambil bagian dari MTsN (Madrasah Tsanawiyyah Negeri) Jember dan SMPIT (Sekolab Menengah Pertama Islam Terpadu) Al-Ghazali Jember. Hasil penelitian ini menunjukkan komponen kepala sekolah di masing-masing sekolah Islam berjumlah satu dengan nilai eigen 6,3081 dan 6,1140. Berdasarkan hasil penelitian ini, beberapa variabel memberikan kontribusi yang signifikan terhadap elektabilitas sekolab dan ini dilakukan dengan melanjutkan analisis sampai nilai proporsi lebih besar dari 80 persen. Variabel kepala sekolah, guru dan suasana belajar mempengarubi keterpiliban sekolah di MTs Negeri 5 Jember dan variabel kepala sekolah, guru dan infrastruktur memengarubi keterpilihan sekolah secara signifikan di SMPIT Al-Ghazali.
\end{abstract}

Kata Kunci: Daya Saing, Lembaga Pendidikan Islam, Komponen Utama, Kepuasan Pelanggan 


\section{INTRODUCTION}

The reputation of educational institutions is reflected in the dimensions of customer or user satisfaction in this context students and their parents (Wong, et. al., 2016). This applies to any type of educational intitutions in Indonesia including those with Islamic identities such as pesantren (Islamic boarding school), madrasa (Islamic formal educational institution) and schools in general (Akhiruddin, 2015). On the part of school manager, it takes serious effort dealing with many components associated with educational resources, such as such as the curriculum, the quality of the teacher/educator, the infrastructure, financing and others to maintain and secure good reputation of their school (Hermawan, 2010).

For Islamic education institutions, the effort and process of school component refinement will need to go through clear and appropriate mappings (Cahyono, et. al., 2015, Isnaini, 2012; Sukriani, et. al., 2010). This effort can be to ensure their existence (Haningsih, 2008), and at the same time to secure their Islamic identity as the core value of Islamic education institutions (Dacholfany, 2015). All these aspects are important to consider because they are essential to maintain the authenticity of Islamic education, which lies in the dimension of learning Islamic values based on monotheism and morality as the essence in shaping the perfect human being (Elihami \& Syahid, 2018; Magdalena, 2017; May, A. (2015 Halstead, 2004, 2007). All those attempts are administered to actualize the goals underpinning the learning process. which is highly multidimensional, multicultural, integrative-interconetive, integrative-transformative and holistic (Ahyat, 2017; Arif, 2011; Hidayat, 2014; Hidayat, 2015).

Islamic educational institutions must be able to realize the goals previously mentioned so that they are able to maintain quality and improve their customer satisfaction (Alkire, et. al., 2015). Having succeed to maintain customer satisfaction, they are in position to enhance or, at least, maintain customer loyalty (Heskett, 2002; Johnson, 2015; Khadka \& Maharjan, 2017). Furthermore, they are likely to achieve the concrete impact that is Islamic School Electability in Indonesian education market.

To achieve school electability, Islamic school should map carefully and precisely their potential to develop (Sujoko, 2017). The implementation of school potential mapping can be done by measuring the level of educational services provided to customers by the Islamic school whether primary, secondary and tertiary identified from customer satisfaction. Furthermore, the analysis tool that can be used in the mapping are SERQUAL, QFD and others (Abili, et.al., 2011); Bier \& Cornesky, 2001; Browne, et. al., 1998; Gonzalez, et. al., 2008; Mansori, et. al., 2014; Sahney, et. al., 2004). The results of the evaluation and measurement can generate fishbone that is helpful to improve all resources pertaining to certain Islamic educational institutions (Slameto, 2016).

Studies on madrasa management implementation have been conducted by researchers. (Mundir, 2015) investigated the implementation TQM in improving the competitiveness of madrasa. Arif (2013) studied the management of madrasa in an effort to improve the quality of education. However, studies investigating the competitiveness and quality of Islamic educational institutions to espouse the school electability have not been conducted intensively. This study tries to fill the gap. The current study is aimed at examining Islamic educational institutions' potential resources by observing the perspective of customers or users (e.g., parents or students) directly. Recruiting students as respondents also help ensure the "directness" of the measurement of educational services provided by Islamic education institutions.

\section{METHOD}

This study applied quantitative to identify variables that become main components of the target educational institution. It also allowed the researchers to use large respondents to 
confirm the level of validity of research results (Creswell, 2015; Creswell, 2016). Nine variables encapsulated in the current study included the principal, teachers, infrastructure, cost, curriculum, accreditation, extracurricular and learning activities and school atmosphere. Data were collected through a questionnaire and were tabulated by referring to the Likert scale. The sample sized was determined by using the Slovin's formula with a margin of error of 5 percent (Amirin, 2011). In the end, a total of 204 students, with details of 73 students from SMPIT (Sekolah Menengah Pertama Islam Terpadu/Islamic Integrated Junior High School) Al-Ghazali and 131 students from MTsN (Madrasah Tsanawiyyah Negeri/State Islamic Junior High School) 5 Jember participated in the study. The two schools were selected because of several reasons: First, their accreditation namely B accredited for MTsN 5 Jember and C accredited for SMPIT Al-Ghazali, Second, the level of difficulty of their selection of prospective students, and third, reasonable number of prospective student accepted.

This study was conducted between May and November 2019. The Principal Component Analysis (PCA) was used to analyze the data. It was used to look at the variables which support the strengths of Islamic educational institutions explicitly. This method of analysis was applied to avoid the multi collinearity of independent variables (Jolliffe, 2002). Finally, the use of this analytic method served to see the variables that contribute significantly to the level of electability of Islamic educational institutions. The research framework can be described as follows:

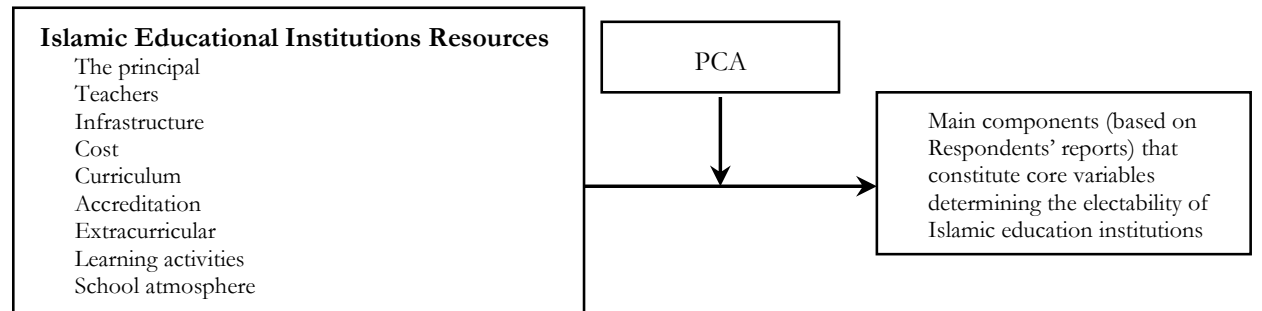

Figure 1. The Framework for Investigating the Electability of Islamic Education Institution.

\section{RESULTS AND DISCUSSION}

This study aims to identify the main components that become dominant variables affecting the electability, or the level of electability of Islamic educational institutions. Referring to the variables used in this study, there is a possibility of "double effects" of the independent variables on the dependent variable. To reduce this possibility, PCA analysis helps identify those dominant variables that affect the electability of Islamic education institutions.

The results of this study underpin the process of mapping in locating the potential strengths of Islamic educational institution resources, so they can be used as a reference in policy or decision making and in strengthening the brand image in order to increase the electability of Islamic educational institutions. The difference in potential components or resources owned by Islamic educational institutions is proportional to the strategic decisions made. In addition, creating opportunities in accordance with the potential strength of the resources seems more rational than participating in the arena of irrelevant competition (Kim \& Maurborgne, 2008) and, thus, enhance the reputation of Islamic educational institutions.

Electability could be applied to goods, services, people, institutions or parties (Sugono, 2008; Wibowo, 2018). Electability as the concrete form of loyalty for education services received by students and parents formed by the trust as well as commitment (Schirmer, et. al., 2018). The quality which can be embedded to education sector is the quality of educational services process. This means the school successfully produces qualified output which 
generates students' satisfaction. (Maghfuri, 2018; Sudjiani, et. al., 2017; Setiawan, 2018). School electability is attached to education customers that can be seen in public participation (Yaqin, 2016; Normina, 2016).

Electability framework process flow on the output preferences produced by the continuous process (MacLeod \& Urquiola, 2015). The following image is a framework of process flow of electability.

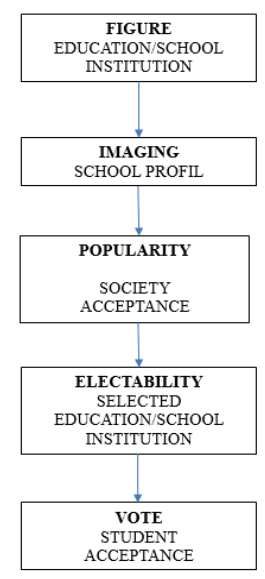

Figure 2. The Process Flow of Electability (Suwardi, et. al, 2016)

Figure 1 illustrates that the process of determining options is closely related to the level of electability that is driven by popularity. The popularity itself is largely influenced by the reinforcement of brand image through the ability of Islamic educational institutions in constructing their profiles in influencing the perspective of prospective users or customers

The initial stage of the results reported below will first describe the values obtained from data analysis (using PCA). The output also displays those variables that meet the eigen value greater than one (and this is interpreted as the dominant variable). Finally, these data are further processed to find identical variables (also interpreted as dominant variables), with a margin of the percentage of principal components with proportion less than and equal 80 .

\section{Result of PCA Research Variables}

Based on the result PCA output generated at SMPIT Al-Ghazali Jember, the score of PC1 is 6.1140, PC2 is 0.8903 and PC3 is 0.6364 with each proportion score is 0.679 (67.9 percent), 0.099 (9.9 percent) and 0,071 (7.1 percent). The results of PCA at MTs. Negeri 5 Jember provides 6.3081 for PC1 output score with 0.701 proportion (70.1 percent), 0.9153 for PC2 with 0.102 proportion (10.2 percent) and 0.4752 for PC3 with 0,053 proportion (5.3 percent). The results output reaching the eigen value which is greater than 1 at each school refer to one principal component. Meanwhile, to reach the variance values that can reach 80 percent, PC2 and PC3 were used. Based on the data, the percentage score at MTsN 5 Jember is 85.6 percent, whereas at SMPIT Al-Ghazali is 84.9 percent. The results of PCA output can be seen in the following figure:
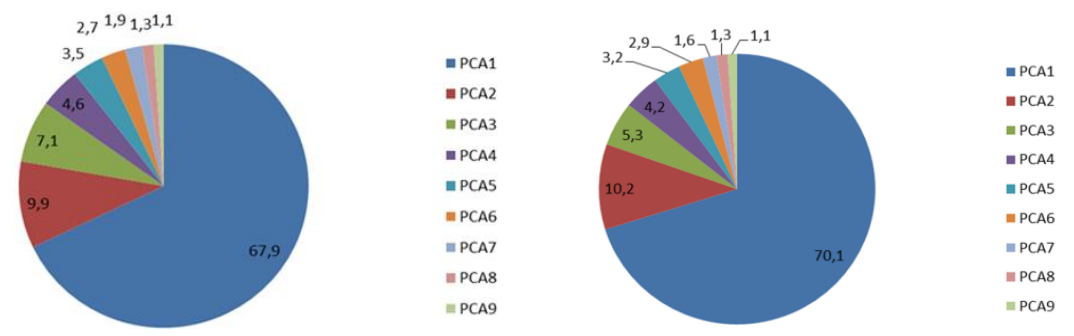

Figure 3. Scatter Diagram of PCA results at SMPIT Al-Ghazali and MTs. Negeri 5 Jember 
The results of the Scree plot for principal component analysis output can be viewed from the following figure:
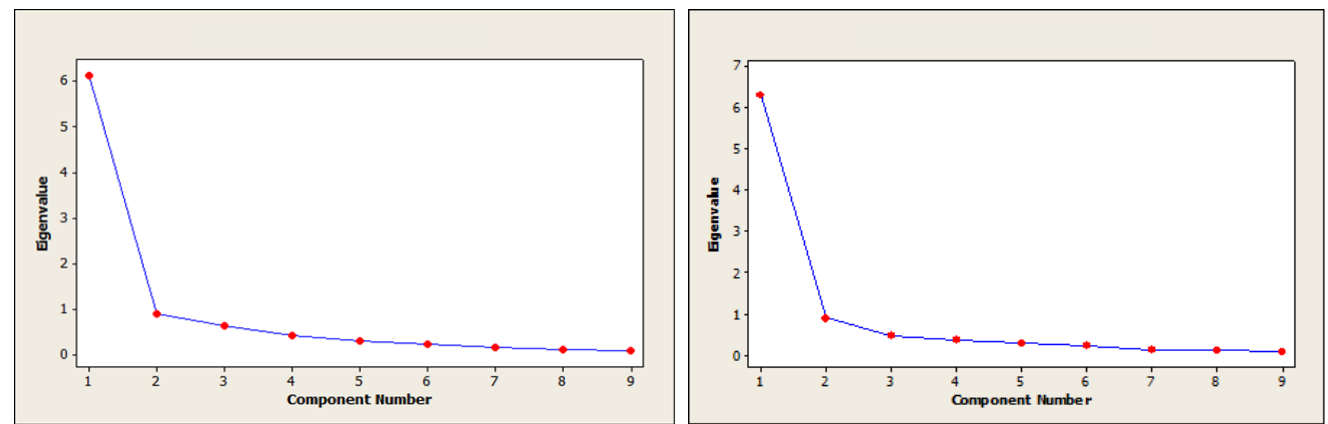

Figure 4. Scree Plot of PCA results at SMPIT Al-Ghazali and MTsN 5 Jember

Based on the data above, to determine the variables having significant contribution, it must use the tabulation of varimax rotation factor:

Table 1. Factor Rotation using Varimax Method on The PCA Data at SMPIT Al-Ghazali and MTsN 5 Jember

\begin{tabular}{|c|c|c|c|}
\hline & \multicolumn{3}{|c|}{ Component } \\
\hline & 1 & 2 & 3 \\
\hline School Principal & 0.254 & -0.648 & 0.405 \\
\hline Educator & 0.346 & -0.008 & 0.428 \\
\hline Infrastructure & 0.251 & -0.506 & -0.707 \\
\hline Cost & 0.310 & 0.310 & -0.253 \\
\hline Curriculum & 0.363 & 0.174 & 0.231 \\
\hline Extracurricular & 0.363 & 0.120 & -0.061 \\
\hline Management & 0.369 & -0.054 & 0.026 \\
\hline $\begin{array}{l}\text { Learning \& Teaching } \\
\text { Process (LTP) }\end{array}$ & 0.369 & 0.234 & -0.012 \\
\hline \multirow[t]{3}{*}{ Atmosphere } & 0.348 & 0.003 & -0.177 \\
\hline & \multicolumn{3}{|c|}{ Component } \\
\hline & 1 & 2 & 3 \\
\hline School Principal & 0.309 & -0.434 & 0.140 \\
\hline Educator & 0.344 & 0.254 & 0.429 \\
\hline Infrastructure & 0.356 & 0.238 & 0.291 \\
\hline Cost & 0.234 & -0.744 & -0.140 \\
\hline Curriculum & 0.351 & -0.059 & 0.239 \\
\hline Extracurricular & 0.368 & 0.097 & 0.184 \\
\hline Management & 0.341 & -0.112 & 0.166 \\
\hline $\begin{array}{l}\text { Learning \& Teaching } \\
\text { Process (LTP) }\end{array}$ & 0.342 & 0.252 & -0.431 \\
\hline Atmosphere & 0.336 & 0.217 & -0.622 \\
\hline
\end{tabular}

Based on the above comparative analysis of the two schools, the results of PCA can be seen in the table below:

Table 2. The Results of PCA on The Islamic Education Institution

\begin{tabular}{|c|c|c|c|c|c|c|c|}
\hline \multicolumn{4}{|c|}{ MTsN 5 Jember } & \multicolumn{4}{|c|}{ SMPIT Al-Ghazali Jember } \\
\hline $\begin{array}{c}\text { Principal } \\
\text { Component }\end{array}$ & $\begin{array}{l}\text { Variable } \\
\text { Name }\end{array}$ & $\begin{array}{l}\text { Loading } \\
\text { Factor }\end{array}$ & $\begin{array}{c}\% \text { Explained } \\
\text { Variance } \\
\end{array}$ & $\begin{array}{c}\text { Principal } \\
\text { Component }\end{array}$ & Variable Name & $\begin{array}{l}\text { Loading } \\
\text { Factor }\end{array}$ & $\begin{array}{c}\% \text { Explained } \\
\text { Variance } \\
\end{array}$ \\
\hline PC-1 & $\begin{array}{l}\text { Principal } \\
\text { Educator } \\
\text { Infrastructure } \\
\text { Curriculum } \\
\text { Curricular } \\
\text { Management } \\
\text { LTP } \\
\text { Atmosphere }\end{array}$ & $\begin{array}{l}0.309 \\
0.344 \\
0.356 \\
0.351 \\
0.368 \\
0.341 \\
0.342 \\
0.336\end{array}$ & 70.1 & PC-1 & $\begin{array}{l}\text { Educator } \\
\text { Cost } \\
\text { Curriculum } \\
\text { Curricular } \\
\text { management } \\
\text { LTP } \\
\text { Atmosphere }\end{array}$ & $\begin{array}{c}0.346 \\
.310 \\
0.363 \\
0.363 \\
.369 \\
.369 \\
0.348\end{array}$ & 67.9 \\
\hline
\end{tabular}




\begin{tabular}{|c|c|c|c|c|c|c|c|}
\hline $\begin{array}{c}\text { Principal } \\
\text { Component }\end{array}$ & $\begin{array}{l}\text { Variable } \\
\text { Name }\end{array}$ & $\begin{array}{c}\text { Loading } \\
\text { Factor }\end{array}$ & $\begin{array}{c}\% \text { Explained } \\
\text { Variance } \\
\end{array}$ & $\begin{array}{c}\text { Principal } \\
\text { Component }\end{array}$ & Variable Name & $\begin{array}{c}\text { Loading } \\
\text { Factor } \\
\end{array}$ & $\begin{array}{c}\text { \% Explained } \\
\text { Variance }\end{array}$ \\
\hline PC-2 & $\begin{array}{c}\text { Principal } \\
\text { Cost }\end{array}$ & $\begin{array}{l}-0.434 \\
-0.744\end{array}$ & 10.2 & PC-2 & $\begin{array}{l}\text { Principal } \\
\text { Infrastructure } \\
\text { Cost }\end{array}$ & $\begin{array}{c}-0.684 \\
-0.506 \\
.310 \\
\end{array}$ & 9.9 \\
\hline PC-3 & $\begin{array}{l}\text { Educator } \\
\text { LTP } \\
\text { Atmosphere }\end{array}$ & $\begin{array}{c}.429 \\
-0.431 \\
-0.622\end{array}$ & 5.3 & PC-3 & $\begin{array}{l}\text { Principal } \\
\text { Educator } \\
\text { Infrastructure }\end{array}$ & $\begin{array}{c}0.405 \\
.428 \\
0.707\end{array}$ & 7.1 \\
\hline & & & 85.6 & & & & 84.9 \\
\hline
\end{tabular}

Referring to the table above, variables that contribute to electability can be mapped by looking at variables having a role in shaping at least 2 principal components. Based on the data of MTsN 5 Jember, the contributing variables consists of principals, educators, learning and school atmosphere. As for SMPIT Al-Ghazali Jember, the contributing variables are costs, principal, infrastructure and educators.

Based on the table 3 description, For MTsN 5 Jember, it can be seen that PC- which accounted 70.1 percent, can be explained by 8 variables, while PC-2, which accounts for 10 percent, can be explained by 2 variables and PC-3, which encompasses a percentage of 5.3 percent, can be explained with 3 variables with the total number of percentages by 85.6 percent. The variables that play a role in constructing the principal component are dominantly the principal variable. On the other hand, for SMPIT Al-Ghazali, PC-1 was formed by 7 variables from 9 research variables, PC-2 was formed by 3 variables and PC-3 was formed by 3 variables. PC-1 can explain 67.9 percent of variables that influence the level of electability of Islamic educational institutions, PC-2 explains 9.9 percent and PC-3 explains 7.1 percent with a total of 84.9 percent.

Based on the results of data analysis presented above, the variables that played a role in forming the principal component are the principal variable. Another variable is the educator/teacher variable which can also be considered as the dominant variable. It primarily contributes only to the formation of the principal component (in other words, the principal variable still shows a bigger contribution than the educator/teacher variable. The conclusion from the display of the data above can thus be explained that the principal variable had contributed significantly to the electability level of Islamic educational institutions.

\section{The Principal Component of Electability Islamic Education Institution}

In line with the results in the preceding section, this study suggests that the principal variable (which constitutes the leadership factor) appears to be the dominant variable that had significantly contributed to the strengthening of brand image in espousing the electability of Islamic educational institutions. There are many roles that principals should play to contribute and improve the electability of their schools. The emergence of principal as a dominant factor has indicated that the principal had the ability to translate users' needs and desires (parents or students). To meet the demand from users, student activities in developing their potential and competence should be catered. This argument is in line with the central principal's role as "a top manager" in the domain of managing Islamic educational institutions.

The effectiveness of the principal in improving the quality of education and resources, especially human resources such as students, teachers, education personnel and others (Mahardhani, 2015; Hattahin \& Widodo, 2019; Suciningtyas, 2019) has improved the electability level of Islamic education institutions. In this study, the principal had the ability to develop the quality of human resources. This ability has an impact on the effectiveness of the institution's performance (Samiruddin \& Husain, 2016) which in turns empowers the electability of Islamic educational institutions. In addition, the principal's ability to develop the quality of human resources on the other hand will influence the potential improvement of 
schools so that they can create a good organizational culture (Leithwood, et. al., 2008; Amanchukwu, et. al., 2015). To this end, the principal has a significant role in developing Islamic educational institutions. This perspective provides the basis that appropriate leadership model should be adopted by a principal to develop Islamic educational institutions. One of the leadership models is a transformational leadership which features the characteristics of critical thinking, creativity, communication and collaboration. This leadership model can encourage the principal to achieve the effectiveness of educational institutions management (Baptiste, 2019), and to increase an institutional reputation.

Another variable that had contributed to the electability of Islamic education institutions in schools is educators/teachers. Although its Eigen value is not greater than 1, it had contributed significantly to the formation of the main components in this study. There are some explanations for this. Previous studies reported that teachers can have a significant influence on student satisfaction who are the user, or customer, of educational services (Zahoor, 2018). Teachers play a pivotal role in maintaining the existence of their school, such as inhibiting the shift selection and school dropouts (Lessard, et. al., 2010). Their ability to strengthen students' loyalty in school selection is inseparable from students' experience that they had received.

Principals should be able to provide a convenience for teachers so they can perform their tasks well. It is necessary that the principal pay attention to all dimensions relating to teachers/educators. Teachers' performance can be related to student satisfaction and they are two inseparable sides which lead to the performance of Islamic educational institutions (Bakotic, 2016). Teachers' efficacy, psychological and physical conditions contribute to their performance in serving students and in shaping students' satisfaction (Hammond, 2000; Spilt, et. al., 2011; Canrinus, et. al., 2012; Kunter et al., 2013; Shen, et al., 2015). Teachers' best performance leads to qualified learning process and this is the key to the successful educational service. It goes without saying that successful education practice in a school brings big impact on the reputation of Islamic education institution.

Concerning the component of costs, this study found that it is not the main variable that forms the principle component of the electability of Islamic educational institutions. The two educational institutions that this study investigated had a significant difference in the cost of education. The cost of education is not the main reason for the electability of Islamic educational institutions. This description illustrates that low costs do not necessarily become advantages for a particular institution. Likewise, high costs are not necessarily weaknesses for a particular institution. Cost of education can therefore be considered as an important variable but it is not a main aspect of the formation of the reputation and image of the school. The affordable education costs, trying not say that it is cheap or even free, become a dimension affecting the electability of Islamic educational institutions. The institutions of modern education today for example Al-Izzah, Al-Hikmah, Muhammadiyah Boarding School (MBS) and some other Islamic education institution whose education costs are above the average have high level of electability. This happens because those education institutions have the ability to describe component of cost into a flagship program of the school. The programs provide comprehensive perspective to the customers towards cost variable element. The component of cost in education arranged by the Islamic school does not have a negative impact but it is likely to be positive in presenting perspective to the quality of services that the school provide.

The component of cost becomes a factor that is no longer relevant in the consideration of customer satisfaction namely students and parents. The satisfaction of students and parent will determine the electability of school. Students and their parent consider component of 
cost as something to do with the quality and service that they will obtain (Togatorop 2010, Halimah, 2013). This fact can be explained in the following picture:

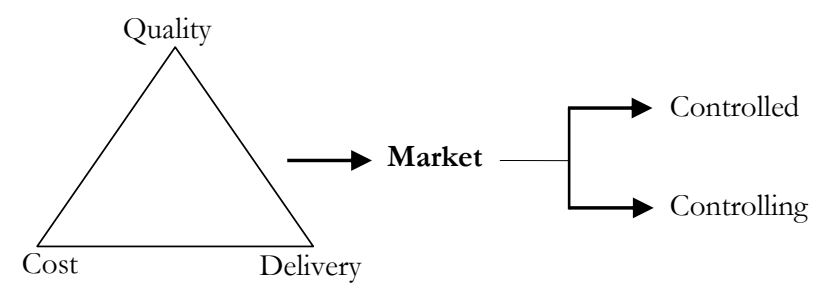

Figure 5. The Position of Customer in Education with Respect to the Cost, Service and Quality of Educational Services

Electability of Islamic education institutions is determined by the quality of the school resources construction. The cost and service in the education process shape market controlling meaning that the educational institutions can control their market share.

Infrastructure and atmosphere of the school can be categorized as complementary variable component in this study. Those components contribute in shaping principal component of Islamic education institutions electability. They sometimes come out as a decisive factor when the education service dimensions of the various school are considered (Waluyo, 2018). The infrastructures, the cost of education and the school atmosphere factors including the ease of access and the school location can contribute the desirability/electability of the school.

Various components of school resources like school principals, teachers, teaching, infrastructure and cost with maximum performance levels produce a concrete level of Islamic school electability (Bayer \& McMillan, 2012). Those components for sure will shape students' satisfaction. Students as recipients have the freedom to interpret educational services they receive from the school. Their satisfaction should be taken into consideration by school manager. It is necessary for the Islamic education institutions to build their reputation and image (Wong, et. al., 2016). Their successful reputation will establish the educational service quality and it will generate customer satisfaction and Islamic school electability (Seng \& Ling, 2013; Setiawan, 2018). The electability of Islamic education can boost human resource of Islamic education institution (Cahyo, 2016) and serves as one solution to the problem of Islamic education institution (Damopoli, 2015)

This study explored Islamic school electability in the perspective of its customer. It is expected that this study contributes to the body of knowledge in Islamic education. A particular attention has been given Islamic school electability and its relation with several components. This study is limited to comparing two Islamic educational institutions. It is suggested that further study will involve more Islamic educational institutions as the sample for the study.

\section{CONCLUSION}

Based on the results and discussion in the previous section, some conclusions can be drawn. There are several components that had contributed significantly to the electability of the two Islamic schools. The variables included school principal, teachers, costs, facilities and atmosphere of school (school environment). The electability of MTsN 5 Jember was constructed significantly by several components namely school principals, educators, learning activities and school atmosphere variable. On the other hand, SMPIT Al-Ghazali electability was constructed by the following components: costs, school principals, facilities and educator's variable. 


\section{ACKNOWLEDGMENT}

This research was funded by the Directorate of Islamic Higher Education, Directorate General of Islamic Education, Ministry of Religion Affairs. The scheme belongs to basic research cluster of program study development 2019.

\section{BIBLIOGRAPHY}

Abili, et. al., (2011). Assesing Quality Gap of University Services. The Asian Journal on Quality, 12(2), 167-175. https://doi.org/10.1108/15982681111158724

Ahyat, N. (2017). Metode Pembelajaran Pendidikan Agama Islam. Edusiana: Jurnal Manajemen dan Pendidikan Islam, 4(1), 24-31. https://doi.org/10.30957/edusiana.v4i1.5

Akhiruddin, K. M. (2015). Lembaga Pendidikan Islam di Nusantara. Tarbiya: Jurnal Imu Pendidikan Islam, 1(1), 195-219. Retrieved from https://journal.uinsgd.ac.id/index.php/jurnal-tarbiya/article/view/143

Alkire, T. D., Lupton, N. A., \& Lupton, R. A. (2015). Every Student Counts: Using Customer Relationship Management to Strengthen Student Retention. International Journal of Business, Humanities and Technology, 5(4), 18-27. Retrieved from https://www.ijbhtnet.com/journal/index/472

Amanchukwu, R. N., Stanley, G. J. \& Ololube, N. P. (2015). A Review of Leadership Theories, Principals and Styles and Their Relevance to Educational Management. Journal Management, 5(1), 6-14. https://doi.org/10.5923/j.mm.20150501.02

Amirin, T. M. (2011). "Populasi dan Sampel Penelitian 4: Ukuran Sampel Rumus Slovin". Retrieved from https://tatangmanguny.wordpress.com/category/populasi-dan-sampel/. Online. Accessed April $2^{\text {nd }}$.

Arif, M. (2011). Pendidikan Agama Islam Inklusif Multikultural. Jurnal Pendidikan Islam, Vol.1, No. 1,1-18. https://doi.org/10.14421/jpi.2011.11.1-18

Arif, M. (2013). Manajamen Madrasah dalam Upaya Meningkatkan Mutu Pendidikan Islam. Jurnal Epistemé, 8(2), 416-438.

Bakotić, D. (2016). Relationship Between Job Satisfaction and Organisational Performance. Economic Research-Ekonomska Istrazivanja, 29(1), 118-130. https://doi.org/10.1080/1331677X.2016.1163946

Baptiste, M. (2019). No Teacher Left Behind: The Impact of Principal Leadership Styles On Teacher Job Satisfaction and Student Success. Journal of International Education and Leadership, 9(1), 1-11. Retrieved from https://eric.ed.gov/?id=EJ1212519

Bayer, P., \& McMillan, R. (2010). Choice and Competition in Education Markets. Retrieved from http://homes.chass.utoronto.ca/ mcmillan/comp_1may10.pdf. Accessed $7^{\text {th }}$ April.

Bier, I. D., and Cornesky, R. (2001). Using QFD to Construct a Higher Education Curriculum. Quality Progress, 34(4), 64-68.

Browne, B. A., Kaldenberg, D. O., Browne, W. G., and Brown, D. J. (1998). Student as Customer: Factors Affecting Satisfaction and Assessments of Institutional Quality. Journal of Marketing for Higher Education. 8(3), 1-14. https://doi.org/10.1300/J050v08n03_01

Cahyo, A. N. (2016). Manajemen Sumber Daya Manusia (SDM) Pendidikan dalam Meningkatkan Daya Saing SDIT Ar Rahmah, Pacitan. Muslim Heritage: Jurnal Dialog Islam dengan Realitas. 1(2), 263-286. https://doi.org/10.21154/muslimheritage.v1i2.600

Cahyono, L. E., Wibowo, S. B., \& Murwani, J. (2015). Analisis Penerapan 8 Standar Nasional Pendidikan pada SMP Negeri 2 Dolopo Kabupaten Madiun. Assets: Jurnal Akuntansi dan Pendidikan, 4(2), 99-105. http://doi.org/10.25273/jap.v4i2.684 
Canrinus, E. T., Lorenz, M. H., Beijaard, D., Buitink, J., \& Hofman, A. (2012). Self-Efficacy, Job Satisfaction, Motivation and Commitment: Exploring The Relationships Between Indicators of Teachers' Professional Identity. European Journal of Psychology of Education, 27(1), 115-132. https://doi.org/10.1007/s10212-011-0069-2

Creswell, J. W. (2015). Riset Pendidikan: Perencanaan, Pelaksanaan, dan Evaluasi Riset Kualitatif \& Kuantitatif Edisi Kelima. Yogyakarta: Pustaka Pelajar.

Creswell, J. W. (2016). Pendekatan Metode Kualitatif, Kuantitatif dan Campuran Edisi ke 4. Yogyakarta: Pustaka Pelajar.

Dacholfany, M. I. (2015). Reformasi Pendidikan Islam dalam Menghadapi Era Globalisasi: Sebuah Tantangan dan Harapan. Jurnal Akademika, 20(01), 173-194. Retrieved from http://e-journal.metrouniv.ac.id/index.php/akademika/article/view/441

Damopoli, M. (2015). Problematika Pendidikan Islam dan Upaya-Upaya Pemecahannya. Tadbir: Jurnal Manajemen Pendidikan Islam, 3(1), 68-81.

Elihami \& Syahid, A. (2018). Penerapan Pembelajaran Pendidikan Agama Islam Dalam Membentuk Karakter Pribadi Yang Islami. Jurnal Edumaspul, 2(1), 79-06. https://doi.org/10.33487/edumaspul.v2i1.17

Gonzalez, M. E., Quesada, G., Gourdin, K., \& Hartley, M. (2008). Designing A Supply Chain Management Academic Curriculum Using Qfd and Benchmarking. Quality Assurance in Education, 16(1), 36-60. https://doi.org/10.1108/09684880810848404

Halimah, A. H., \& Munir. (2013). Pengaruh Mutu Layanan Guru dan Biaya Pribadi terhadap Kepuasan Siswa pada SMP Swasta Se-Kota Tasikmalaya. Jurnal Administrasi Pendidikan, 17(1), 40-50. https://doi.org/10.17509/jap.v17i1.6431

Halstead, M. (2004). An Islamic Concept of Education. Comparative Education, 40(4), 517-529.

Halstead, J. M. (2007). Islamic Values: A Distinctive Framework for Moral Education?. Journal of Moral Education, 36(3), 283-296. https://doi.org/10.1080/0305006042000284510

Hammond, L. D. (2000). Teacher Quality and Student Achievement: A Review of State Policy Evidence. Educational Policy Analysis Archives, 8(1), 1-44.

Haningsih, S. (2008). Peran Strategis Pesantren, Madrasah dan Sekolah Islam di Indonesia. ElTarbawi Jurnal Pendidikan Islam, 27-39. https://doi.org/10.20885/tarbawi.vol1.iss1.art3

Hattahin \& Widodo, E. (2019). Peran Kepala Sekolah sebagai Pemberdayaan Sumber Daya Manusia di SMA Berbasis Islam Bangkalan Madura. Jurnal Kebijakan dan Pengembangan Pendidikan, 7(2). https://doi.org/10.22219/jkpp.v7i2.12055

Hermawan, R. (2010). Pengembangan Sumber Daya Sekolah. Jurnal Pendidikan Dasar. Retrived from: http://file.upi.edu/Direktori/JURNAL/PENDIDIKAN_DASAR/ Nomor_13April_2010/Pengembangan_Sumber_Daya_Sekolah-Ruswandi_Hermawan.pdf.

Heskett, J. L. (2002). Beyond Customer Loyalty. Managing Service Quality: An International Journal. Vol. 12, No. 6, 355-357. https://doi.org/10.1108/09604520210451830

Hidayat, M. (2014). Pendekatan Integratif-Interkonektif: Tinjauan Paradigmatik dan Implementatif dalam Pembelajaran Pendidikan Agama Islam. Jurnal Ta'dib, XIX(02), 276287.

Hidayat, N. (2015). Peran dan Tantangan Pendidikan Agama Islam di Era Global. Jurnal ElTarbawi, VIII(2), 131-145. https://doi.org/10.20885/tarbawi.vol8.iss2.art2

Isnaini, M. (2012). Pola dan Strategi Manajemen Berbasis Sekolah dalam Menghadapi Persaingan Mutu. Ta'dib: Journal of Islamic Education, 17(01), 83-101. https://doi.org/10.19109/tjie.v17i01.27

Johnson, M. D. (2015). Customer Satisfaction. In International Encyclopedia of the Social \& Behavioral Sciences: Second Edition. James D. Wright (Ed), 630-632.

Jolliffe I. T. (2002). Principal Component Analysis Second Edition. NewYork (US): Springer-Verlag. 
Kim, W. C. \& Mauborgne, R. (2008). Blue Ocean Strategy: Menciptakan Ruang Pasar Tanpa Pesaing dan Menjadikan Persaingan Tidak Lagi Relevan. (Terj. Satrio W. Jakarta: PT. Serambi Ilmu Semesta.

Kunter, M., Klusmann, U., Baumert, J., Richter, D., Voss, T., and Hachfeld, A. (2013). Professional Competence of Teachers: Effects on Instructional Quality and Student Development. Journal of Educational Psychology. 105(2), 805-820. https://doi.org/10.1037/a0032583

Leithwood, K., Harris, A., \& Hopkins, D. (2008). Seven Strong Claims About Successful School Leadership. School Leadership and Management. 28(1), 27-42. https://doi.org/10.1080/13632430701800060

Lessard, A., Poirier, M., \& Fortin, L. (2010). Student-Teacher Relationship: A Protective Factor Against School Dropout?. Procedia - Social and Behavioral Sciences, 2(2), 1636-1643.

Samiruddin \& Husain, Y. S. (2016). Impact of Human Resource Quality and Bureaucracy Behaviour on Organizational Performance Effectiveness. International Journal of Science and Research (IJSR), 5(2), 881-885. Retrieved from

Seng, E. L. K., \& Ling, T. P. (2013). A Statistical Analysis of Education Service Quality Dimensions on Business School Students' Satisfaction. International Education Studies, 6(8), 136-146. https://doi.org/10.5539/ies.v6n8p136

Suciningtyas, R. (2019). Leadership of School Headmaster in Improving the Quality of Education. Proceeding the 3rd International Conference on Education Innovation (ICEI 2019), 3(1), 59-61.

MacLeod, W. B., \& Urquiola, M. (2015). Reputation and School Competition. American Economic Review, 105(11), 3471-3488. https://doi.org/10.1257/aer.20130332

Magdalena. (2016). Konstruksi Muslim Kaffah dalam Kurikulum Terpadu di Sekolah Islam Terpadu. Proceeding LAIN Batusangkar, 1(1), 475-488.

Mahardhani, A. J. (2015). Kepemimpinan Ideal Kepala Sekolah. Jurnal Dimensi Pendidikan dan Pembelajaran, 3(2), 1-4. https://doi.org/10.24269/dpp.v3i2.82

Khadka, K., \& Maharjan, S. (2017). Customer Satisfaction and Customer Loyalty. Retrieved from: https://core.ac.uk/download/pdf/161421179.pdf. 1-54.

Mansori, S., Vaz, A., \& Ismail, Z. M. M. (2014). Service Quality, Satisfaction and Student Loyalty in Malaysian Private Education. Journal Asian Social Science, Vol. 10, No. 7, 57-66.

May, A. (2015). Melacak Peranan Tujuan Pendidikan dalam Perspektif Islam. Tsaqafah: Jurnal Peradaban Islam, 11(2), 209-222. http://dx.doi.org/10.21111/tsaqafah.v11i2.266

Mundir, A. (2015). Impelmentasi Total Quali ty Management untuk Meningkatkan Daya Saing Lembaga Pendidikan Madrasah. At-Tajdid: Jurnal Ilmu Tarbiyah, Vol. 4, No. 1, 93-106.

Normina. (2016). Partisipasi Masyarakat dalam Pendidikan. Ittihad Jurnal Kopertais Wialyah XI Kalimantan, 14(26), 71-85.

Sahney, S., Banwet, D. K., \& Karunes, S. (2004). A Servqual and QFD Approach to Total Quality Education: A Student Perspective. International Journal of Productivity and Performance Management, 53(2), 143-166. https://doi.org/10.1108/17410400410515043

Schirmer, N., Ringle, C. M., Gudergan, S. P., \& Feistel, M. S. G. (2016). The Link Between Customer Satisfaction and Loyalty: The Moderating Role of Customer Characteristics. Journal of Strategic Marketing, 26(4), 298-317. https://doi.org/10.1080/ 0965254X.2016. 1240214

Setiawan, B. A. (2018). Tingkat Kepuasan Pelanggan Terhadap Layanan Pendidikan di SD Integral Lukman Al-Hakim Jember. Tarlim: Jurnal Pendidikan Agama Islam, 1(2), 73-84. https://doi.org/10.32528/tarlim.v1i2.1702 
Shen, B., McCaughtry, N., Martin, J., Garn, A., Kulik, N., \& Fahlman, M. (2015). The Relationship Between Teacher Burnout and Student Motivation. British Journal of Educational Psychology, 85(4), 519-532. https://doi.org/10.1111/bjep.12089

Slameto. (2016). The Application of Fishbone Diagram Analisis to Improve School Quality. Dinamika Ilmu: Journal of Education, 16(1), 59-74. https://doi.org/10.21093/di.v16i1.262

Sugono, D. (2008). Kamus Besar Bahasa Indonesia Edisi Keempat. Jakarta: Gramedia Pustaka Utama.

Sujoko, E. (2017). Strategi Peningkatan Mutu Sekolah Berdasarkan Analisis SWOT di Sekolah Menengah Pertama. Kelola: Jurnal Manajemen Pendidikan, 4(1), 83-96. https://doi.org/10.24246/j.jk.2017.v4.i1.p83-96

Sukriani, Huda A.Y, M., Arifin, I., \& Suriansyah, A. (2017). The implementation of the Islamic Schools resources total quality management in Banjarmasin, Indonesia (A Multicase Study at State Islamic Primary School of Pemurus Dalam, State Islamic Middle School of Mulawarman, and State Islamic High School of Banjarmasin 3). Journal of Social Science (COES\&RJ-JSS), 6(1), 125-138.

Suwardi, Y. P., Azhar, M. A., \& Apriani, K. D. (2016). Faktor Figur Dalam Keterpilihan Anggota DPRD Studi Kasus: Keterpilihan Anggota DPRD dari Partai Gerindra Kabupaten Klungkung pada Pemilu 2014. E-Jurnal Politika, 1(1), 1-13.

Spilt, J. L., Koomen, H. M. Y., \& Thijs, J. T. (2011). Teacher Wellbeing: The Importance of TeacherStudent Relationships. Educational Psychology Review 23, 457-477.

Togatorop, M. (2017). Pengaruh Biaya Pendidikan Terhadap Mutu Sekolah SMA Swasta. Scholaria: Jurnal Pendidikan dan Kebudayaan, 7(3), 234-240. https://doi.org/10.24246/j.scholaria.2017.v7.i3.p234-240

Waluyo, S. E. Y. (2018). Analisa Pengaruh Lokasi, Biaya dan Kualitas Pendidikan Terhadap Minat Siswa Memilih Sekolah SMA Muhammadiyah 2 Mojosari di Mojokerto. JEBDEER: Journal of Entrepreneurship, Business Development and Economic Educations Research, 1(2), 49-58. https://doi.org/10.32616/jbr.v1i2.69

Wibowo, E. A. (2018). Akuntabilitas Partai Politik Dan Elektabilitas Partai Politik: Studi Kasus Pada Partai Politik Peserta Pemilu di Propinsi DIY Tahun 2014. Jurnal Riset Akutansi dan Keuangan, 14(1), 31-40. Retrieved from http://ejournalfb.ukdw.ac.id/index.php/jrak/article/view/297

Wong, A., Woo, A., \& Tong, C. (2016). Student Satisfaction and School Reputation: The Moderating Role of Student Loyalty and School Image. Journal of Marketing and HR (JMHR), Vol. 2, Issue 1, 113-125. Retrieved from: http://www.scitecresearch.com/ journals/index.php/jmhr/article/view/611.

Yaqin, A. A., \& Kristanto, A. (2016). Strategi Pemasaran Pendidikan Di Madrasah Aliyah Unggulan Pondok Pesantren Amanatul Ummah Surabaya. Jurnal Inspirasi Manajemen Pendidikan, 4(1). Retrieved from https://jurnalmahasiswa.unesa.ac.id/ index.php/inspirasi-manajemen-pendidikan/article/view/15903

Zahoor, A. (2018). Teacher Proactivity Influencing Student Satisfaction and Loyalty Role of Job Crafting and Work Engagement. VIKALPA: The Journal for Decision Makers, 43(3), 125-138. https://doi.org/10.1177/0256090918785046 